\title{
Optimizing the assessment of motor skills in 6th grade pupils through multimedia means
}

Authors' Contribution:

A Study Design

B Data Collection

C Statistical Analysis

D Data Interpretation

E Manuscript Preparation

F Literature Search

G Funds Collection

\author{
Paul Szabo-Alexi ${ }^{1}$ ACDEF, István Pocsai ${ }^{2}$ BCDF, Mariana Szabo-Alexi ${ }^{1}$ ADEF \\ ${ }^{1}$ Faculty of Geography, Tourism and Sport, University of Oradea, Oradea, Romania \\ 2 "Arany János" High School, Salonta, Romania
}

abstract

Background: In this paper we propose to analyze ways to introduce multimedia methods in the evaluation process in the discipline of physical education and sports, by increasing the objectivity of evaluation and selfevaluation.

Material and methods:

During the research, 20 students aged 12-13 were filmed and evaluated. Movement analysis software, Kinovea application, version 0.8 .15 , was used to analyze the recorded image.

Results: Through the centralized data represented in graphs and tables, at the first evaluation, the control group obtained results closer to the execution model by an average of $0.62 \%$ in 5 of the 6 samples. Following the application of the method researched in the paper, namely the viewing of the records from the first evaluation with biomechanically analyzed frames, the relationship between the two groups changes. At the final evaluation, the research group obtains results closer to the execution model in all 6 samples, on average by $-4.61 \%$.

Conclusions: The results obtained after applying the statistical parameters (mean) of video recording and analysis reveal a progress in the technical preparation of students, the mistakes being detected more easily and more concretely, the students forming a clear image of their own execution and mistakes.

Key words: movement, evaluation, multimedia, physical education, biomechanical analysis, Kinovea.

\section{article details}

Article statistics: Word count: 2,939; Tables: 5; Figures: 7; References: 21

Received: June 2021; Accepted: October 2021; Published: November 2021

Full-text PDF: http://www.balticsportscience.com

Copyright @) Gdansk University of Physical Education and Sport, Poland

Indexation: Celdes, Clarivate Analytics Emerging Sources Citation Index (ESCI), CNKI Scholar (China National Knowledge Infrastructure), CNPIEC, DOAJ, EBSCO - Central \& Eastern European Academic Source, EBSCO - SPORTDiscus, EBSCO Discovery Service, Google Scholar, Index Copernicus, J-Gate, Naviga (Softweco, Primo Central (ExLibris), ProQuest - Family Health, ProQuest - Health \& Medical Complete, ProQuest - Illustrata: Health Sciences, ProQuest Nursing \& Allied Health Source, Summon (Serials Solutions/ProQuest, TDOne (TDNet), Ulrich's Periodicals Directory/ ulrichsweb, WorldCat (OCLC)

Funding: This research received no specific grant from any funding agency in the public, commercial, or not-for-profit sectors.

Conflict of interests: Authors have declared that no competing interest exists. Paul Szabo-Alexi; Faculty of Geography, Tourism and Sport, University of Oradea; email: pszabo@uoradea.ro

This is an open access article distributed under the terms of the Creative Commons Attribution-Non-Commercial-NoDerivatives 4.0 International (https://creativecommons.org/licenses/by-nc-nd/4.0/), which permits use, distribution, and reproduction in any medium, provided the original work is properly cited, the use is non-commercial and is otherwise in compliance with the license. 


\section{INTRODUCTION}

The possibilities offered by multimedia techniques in the field of physical education and sports, at any stage, have forced teachers, instructors and coaches to introduce these new elements in physical education and sports, sports training or training. These tools are developed as means of investigation through which it is possible to observe and research aspects that are not detectable through traditional observational methods [1-3].

Evaluation is an important part of the instructive-educational process, through which the efficiency of the teaching process is verified, measuring the level of mastering the technical elements, the motor performance achieved, as well as establishing the need and direction of methods of improvement and support [4-7].

By using video analysis methods, objective results are obtained. These techniques offer a possibility of a detailed analysis of the execution technique, establishing technical errors, having a role in increasing the achieved motor performance. As a freeware application, Kinovea is a free 2D motion analysis software that can be used to measure kinematic parameters; it can ensure the assessment of movement, and it has been validated as a tool to assess time-related variables, compared to a "golden" model [8-11].

\section{MATERIAL AND METHODS}

During the research, 20 students from the Theoretical High School "Arany János" Salonta, from the 6th grade, were filmed and evaluated (research group), and class of VI.D. was a control group. The students are between 12-13 years old, with 5 boys and 5 girls selected for each group. Subjects were assessed anthropometrically by measuring their height, weight, span, bust height, and length of lower and upper limbs [12-14].

The present research was carried out by video recording of the students' execution during physical education and sports classes, at the beginning of the 2019/2020 school year, captured with the initial, intermediate and final position of the exercises.

The next step after selecting the sample was the filming of the execution model exercise by a chosen performance athlete who practices basketball, athletics and karate at a competitive level [10]. The study continued with the recording of students' performance during physical education and sports classes. The targeted evaluation samples were filmed as part of the evaluation provided in the half-yearly and annual plans, and these films would then be analyzed by the authors. During the image analysis, a free movement application, Kinovea, was used (version 0.8.15) $[15,16]$. The following steps were involved:

- viewing the recordings with idling and identifying the initial, intermediate and final positions;

- marking the joints;

- marking segments;

- calculating angles between segments, at the level of the established joints;

- exporting the data obtained in the .xlsx format, necessary for Microsoft Excel program.

By analyzing the footage from the initial assessment, technical errors in both groups were identified. In the next hour, also scheduled for evaluation in the planning, the students from the research group, in addition to the instructions of the evaluating teacher, viewed the interpreted recordings, in order to offer the possibility of visual self-evaluation. The control group received only instructions, without the possibility to watch the execution from the initial assessment.

Simultaneously with the recording of the evaluation tests, the motor performance was measured in four tests involving speed, throwing a small ball from the standing position, sit-ups and long jump. 


\section{RESULTS}

\section{ANALYSIS OF THE RESULTS OBTAINED BY THE TWO GROUPS RELATED TO THE ACHIEVED PERFORMANCE}

The evaluation of both the research group and the control group was performed in six tests establishing important phases of technical execution. These phases were called the initial, intermediate and final position, after which the respective biomechanical positions were analyzed with the help of the Kinovea program [10].

\section{Analysis of the results obtained in running $50 \mathrm{~m}$}

Within this test, three phases were distinguished analyzing the position of the top start, the first step from the launch and the running step at half distance, $25 \mathrm{~m}$. Through the intermediate position, the moment of contact with the ground was chosen, after performing the first step from the start. Analysis of the running step by capturing an antero-posterior sagittal distance of the lower limbs, made between 20 and $25 \mathrm{~m}$, from the running distance of $50 \mathrm{~m}$

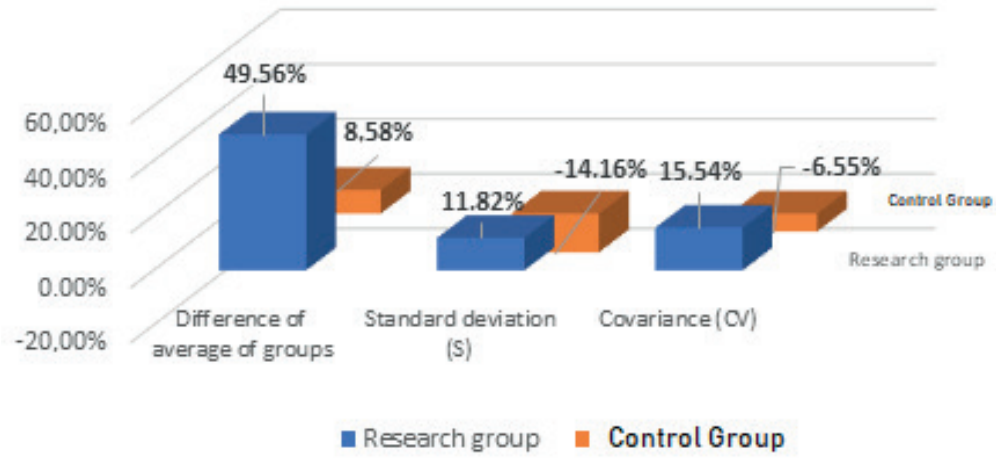

Fig. 1. The difference between the initial and final assessment in speed running, both groups

Checking the data from Fig. 1, we note that although the initial results did not show a major difference between the two groups, the progress is $41 \%$ higher in the research group. Thus, the results of the final evaluation are closer by 7 to the results of the execution model, compared to the control group, where there was an approach of 1.33. At the same time, in the research group we show an increase in the group homogeneity from the decrease in the standard deviation by $11.82 \%$ and of the variability coefficient by $15.54 \%$, compared to the execution model, while in the control group these values increased by $14.16 \%$ and $6.55 \%$, respectively.

Table 1. Group average, motor performance evaluation, speed running

\begin{tabular}{lcccc} 
& \multicolumn{2}{c}{$\begin{array}{c}\text { Speed running results } \\
\text { Initial } \\
\text { assessment }\end{array}$} & Final assessment $\begin{array}{c}\text { The difference } \\
\text { between the two } \\
\text { assessments }\end{array}$ & $\begin{array}{c}\text { Progress or } \\
\text { regression }\end{array}$ \\
\hline Research group & $8.3^{\prime \prime}$ & $8.09^{\prime \prime}$ & $0.27^{\prime \prime}$ & progress \\
Control group & $8.1^{\prime \prime}$ & $8.07^{\prime \prime}$ & $0.04^{\prime \prime}$ & progress \\
Difference between the two groups & $0.2^{\prime \prime}$ & $0.02^{\prime \prime}$ & $0.23^{\prime \prime}$ & \\
\hline
\end{tabular}

We understand that motor performance is not strictly related to the correctness of the execution technique in the speed running test (Table 1). Although the research group made progress of 0.27 " in the final evaluation, the obtained result is not significantly better than in the research group, which has a minimum progress of $0.02 "$, but also good results in the initial evaluation. 


\section{Basketball shoot}

In this evaluation test, the initial position was followed - before starting the execution with a symmetrical ball grip on the side, and the final position - the one after the ball was released.

The segments followed were identical at the two phases, thus analyzing the angles in the joints listed below at: lower limbs, upper limb from the camera, trunk and head of the performer.

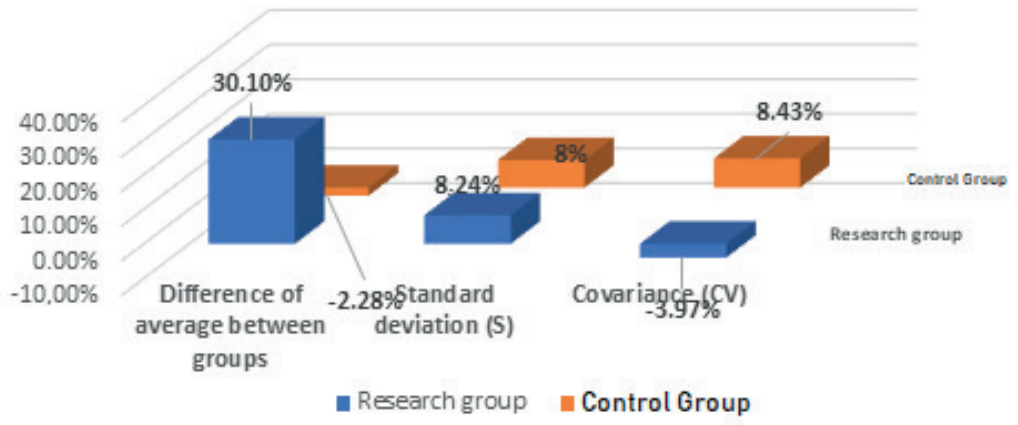

Fig. 2. The difference between the initial and final assessment of basketball shoot, both groups

Following the data from Fig. 2, we observe a progress of $30.10 \%$ in the research group and a slight regression of $-2.28 \%$, in the difference between the group average and the execution model, with about $32.38 \%$ closer to the research group. By decreasing the standard deviation by $8.24 \%$ in the research group, and by $8 \%$ in the control group, the decrease of the dispersion of the results is confirmed.

In both groups there is a change in the coefficient of variables, higher in the research group by $3.97 \%$ and lower by $8.43 \%$ in the control group, reaching values very close to the two groups, 11.10 and 11.52, reporting a relative homogeneity at the final evaluation.

\section{Throwing a small ball from the standing position}

During the execution, three phases (positions) were distinguished, in order to succeed in a more complex and correct analysis of the evaluation test. The segments pursued in the three positions are those with an important role in each phase, so it is very important that these segments are clearly observable in each performer.

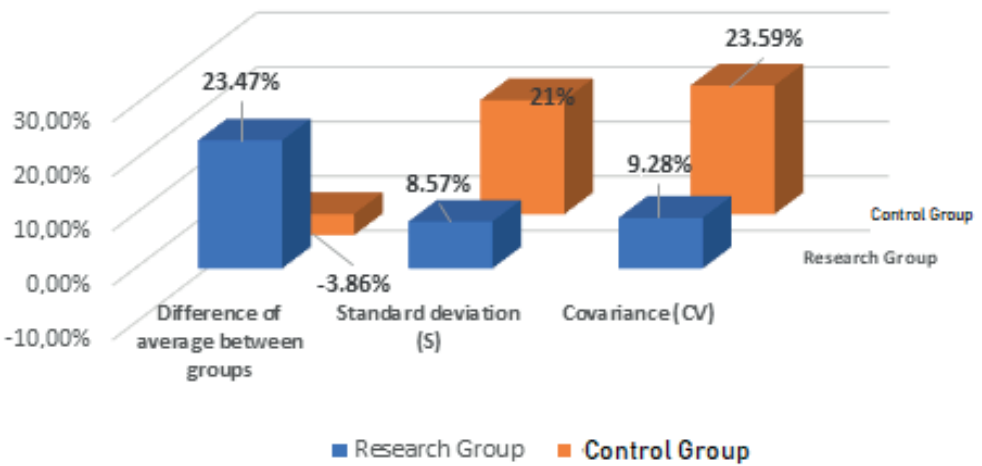

Fig. 3. The difference between the initial and final assessment of small ball throwing, both groups

Fig. 3 tells us that the execution progressed within the research group by $23.47 \%$, and there was a setback of $3.86 \%$ in the control group, with a difference of $27.33 \%$. It is worth 
mentioning that the homogeneity of the group increased by $2.5 \%$ more in the control group, reaching an improvement of $21 \%$ in the standard deviation and $23.59 \%$ in the coefficient of variability, compared to $8.57 \%$ and $9.28 \%$ in the research group.

Table 2 shows us that by improving the technical execution the motor performance when throwing a small ball also increases. Both groups recorded an increase in the final evaluation of the performance, but the subjects in the research group improved their result by $50 \%$ compared to the subjects in the control group, highlighting the fact that the initial result is very close to the two groups, with a minor difference of $0.2 \mathrm{~m}$.

Table 2. Average of groups, evaluation of motor performance, throwing a small ball

\begin{tabular}{lcccc} 
& \multicolumn{4}{c}{ Results obtained when throwing a small ball } \\
& $\begin{array}{c}\text { Initial } \\
\text { assessment }(\mathrm{m})\end{array}$ & $\begin{array}{c}\text { Final assessment } \\
(\mathrm{m})\end{array}$ & $\begin{array}{c}\text { The difference } \\
\text { between the two } \\
\text { assessments }(\mathrm{m})\end{array}$ & $\begin{array}{c}\text { Progress or } \\
\text { regression }\end{array}$ \\
\hline Research group & 19.9 & 21.1 & 1.2 & progress \\
Control group & 19.7 & 20.3 & 0.6 & progress \\
Difference between the two groups & 0.2 & 0.8 & 0.6 & \\
\hline
\end{tabular}

\section{Sit-up}

Three separate phases were analyzed: initial position, intermediate position and final position. In the initial position, the performer is lying on his back on the mattress, with the lower limbs bent, the soles on the ground, the arms bent with the palms at the nape of the neck, the head following the torso. The moment to define the intermediate position was established at the maximum point of lifting the torso, namely the moment of maximum flexion of the torso on the thigh. When the subject went back to the floor before the moment of starting the next execution, the final position was chosen.

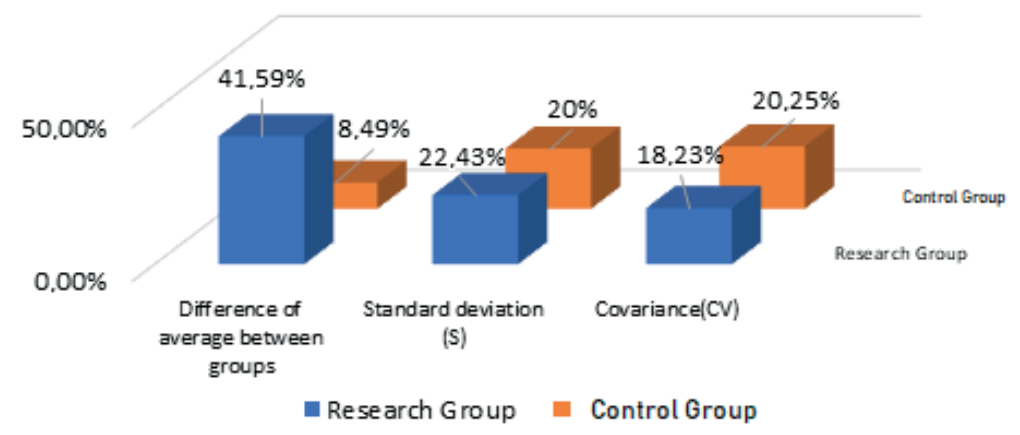

Fig. 4. Difference between the initial and final assessment in sit-ups, both groups

We observe in the data presented in Fig. 4 that both groups made progress in terms of the execution technique, compared to the execution model, but in the research group we see a major progress of $41.59 \%$, while in the control group only by $8.49 \%$.

The homogeneity of the group increased in both samples, showing very close values of the standard deviation and the coefficient of variables with differences of maximum 2.43. 
Table 3. Sit-up - evaluation of the motor performance, average of the groups

\begin{tabular}{lcccc} 
& $\begin{array}{c}\text { Initial } \\
\text { assessment } \\
\left(\text { Pcs } / 30^{\prime \prime}\right)\end{array}$ & $\begin{array}{c}\text { Results obtained at sit-up } \\
\text { Final assessment } \\
(\text { Pcs/30") }\end{array}$ & $\begin{array}{c}\text { The difference } \\
\text { between the two } \\
\text { assessments } \\
\left(\text { Pcs } / 30^{\prime \prime}\right)\end{array}$ & $\begin{array}{c}\text { Progress or } \\
\text { regression }\end{array}$ \\
\hline Research group & 19.6 & 19.3 & 0.3 & Regression \\
Control group & 20.7 & 20 & 0.7 & Regression \\
Difference between the two groups & 1.1 & 0.7 & & \\
\hline
\end{tabular}

We notice that the number of repetitions decreased in both groups following the correction of the execution technique, with 0.3 repetitions in the research group and 0.7 in the control group. We consider this result a natural one, considering that lifting the torso from lying on the back is a test of strength, and the correct execution also implies a difficulty of the exercise. Most likely, at the initial assessment, the subjects performed incomplete repetitions, which facilitated the higher number of repetitions.

\section{Rolling forward}

In this evaluation test, the aim is exclusively to improve the execution technique, not being a technical procedure through which to achieve a measurable motor performance. The evaluation of this element of artistic gymnastics is done by the appreciation of the technique by the evaluator-teacher.

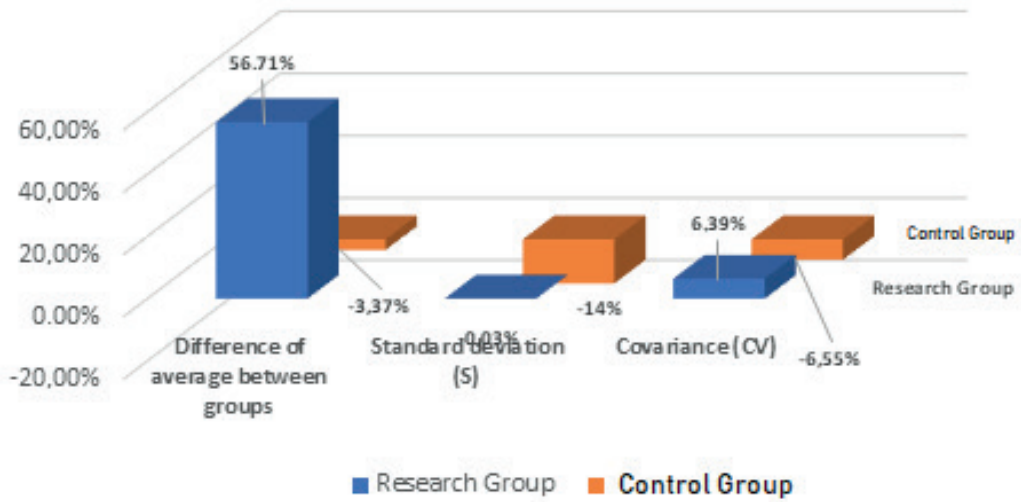

Fig. 5. The difference between the initial and final assessment when rolling forward, both groups

A major difference in progress between the two groups, in favor of the research group, is obvious. Analyzing a technical procedure which is evaluated only by appreciation of the execution technique, the importance of progress (56.71\%) by applying the method of video analysis and self-evaluation is all the more significant. The fact that the homogeneity of the research group is a relative one indicates that the way of perceiving mistakes is not identical, and the ability to synthesize information differs from student to student.

\section{Standing long jump}

Representing a test for evaluating the force in speed regime, in addition to following the execution technique, the length of the jump performed by the students was measured at both evaluations. 


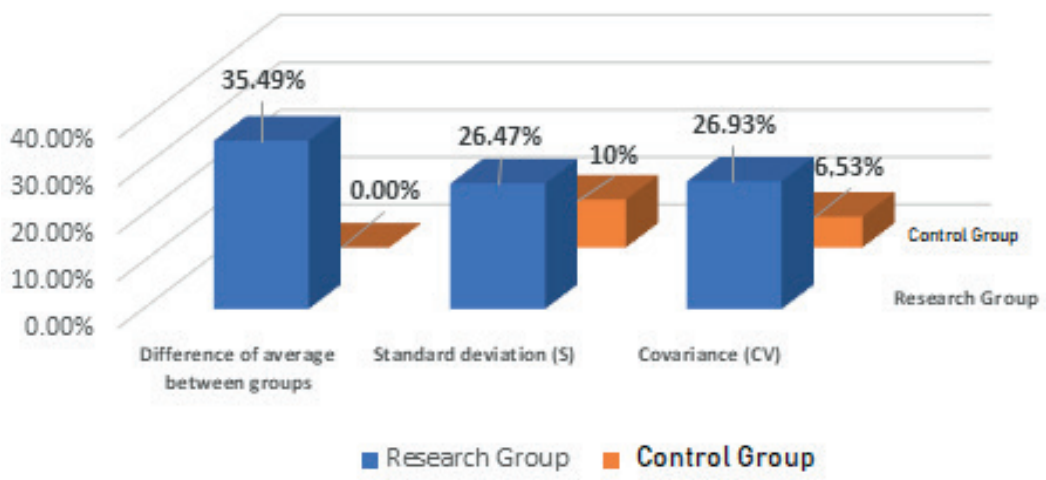

Fig. 6. The difference between the initial and final assessment in standing long jump, both groups

According to Fig. 6, the obvious progress made by the research group and the stagnation of the control group are observed, which confirms the efficiency of the research method used, namely self-evaluation by following one's own analyzed records. The dispersion of results decreased in both groups, increasing homogeneity, but significantly more pronouncedly in the research group. The difference in increase in the standard deviation between the two groups being of $16.47 \%$, and at the coefficient of variability of $20.40 \%$, highlights once again the efficiency of the video analysis method.

Table 4. Average of the groups, evaluation of motor performance, standing long jump

\begin{tabular}{lcccc} 
& \multicolumn{5}{c}{$\begin{array}{c}\text { Results obtained in the standing long jump } \\
\text { Initial } \\
\text { assessment }(\mathrm{cm})\end{array}$} & $\begin{array}{c}\text { Final assessment } \\
(\mathrm{cm})\end{array}$ & $\begin{array}{c}\text { The difference } \\
\text { between the two } \\
\text { assessments } \\
\text { (cm) }\end{array}$ & $\begin{array}{c}\text { Progress or } \\
\text { regression }\end{array}$ \\
\hline Research group & 136.8 & 140.6 & 4 & progress \\
Control group & 137 & 139.5 & 2.5 & progress \\
Difference between the two groups & 0.2 & 1.1 & & \\
\hline
\end{tabular}

Table 4 shows that by improving the technical execution, motor performance also increases, which is demonstrated by a 4 -cm higher result of the research group. Although, according to the data, the execution of the technical element did not show progress in the control group, the subjects' motor performance increased by $2.5 \mathrm{~cm}$. We explain this fact by a high level of concentration in the final evaluation of the students who wanted to correct the highlighted mistakes.

\section{ANALYSIS OF THE RATIO BETWEEN THE GROUP AVERAGE AND THE EXECUTION MODEL}

By analyzing the ratio between the group average and the execution model we want to highlight the progress made by the groups in relation to the benchmark results. Comparing the differences between the results of the initial and final evaluation confirms or not the effectiveness of the method used in the research. 
Table 5. Presentation of the results obtained by both groups compared to the execution model and the difference between the two groups

\begin{tabular}{|c|c|c|c|c|c|c|}
\hline & \multicolumn{6}{|c|}{ Difference between the group average and the execution model } \\
\hline & \multicolumn{3}{|c|}{ Initial assessment } & \multicolumn{3}{|c|}{ Final assessment } \\
\hline & $\begin{array}{l}\text { Research } \\
\text { group }\end{array}$ & $\begin{array}{l}\text { Control } \\
\text { group }\end{array}$ & $\begin{array}{c}\text { Difference } \\
\text { between the } \\
\text { two groups }\end{array}$ & $\begin{array}{l}\text { Research } \\
\text { group }\end{array}$ & $\begin{array}{l}\text { Control } \\
\text { group }\end{array}$ & $\begin{array}{c}\text { Difference } \\
\text { between the } \\
\text { two groups }\end{array}$ \\
\hline Speed running & $16.77^{\circ}$ & $15.54^{\circ}$ & $1.23^{\circ}$ & $8.46^{\circ}$ & $14.21^{\circ}$ & $-5.75^{\circ}$ \\
\hline Bascketball shoot & $12.96^{\circ}$ & $12.67^{\circ}$ & $0.29^{\circ}$ & $9.06^{\circ}$ & $12.96^{\circ}$ & $-3.90^{\circ}$ \\
\hline Throwing a small ball & $9.99^{\circ}$ & $10.90^{\circ}$ & $-0.91^{\circ}$ & $7.64^{\circ}$ & $11.32^{\circ}$ & $-3.67^{\circ}$ \\
\hline Sit-up & $9.62^{\circ}$ & $8.80^{\circ}$ & $0.82^{\circ}$ & $5.62^{\circ}$ & $8.80^{\circ}$ & $-3.18^{\circ}$ \\
\hline Rollover & $11.06^{\circ}$ & $10.23^{\circ}$ & $0.83^{\circ}$ & $4.79^{\circ}$ & $10.57^{\circ}$ & $-5.78^{\circ}$ \\
\hline Long jump & $19.40^{\circ}$ & $17.92^{\circ}$ & $1.49^{\circ}$ & $12.52^{\circ}$ & $17.92^{\circ}$ & $-5.40^{\circ}$ \\
\hline $\begin{array}{l}\text { Average difference } \\
\text { between the two } \\
\text { groups }\end{array}$ & & & $0.62^{\circ}$ & & & $-4.61^{\circ}$ \\
\hline
\end{tabular}

Through the data presented in Table 5, which reflects the centralization of the results from the initial and final evaluation in evaluation samples, we notice that at the first evaluation the control group obtained results closer to the execution model in 5 samples and only in one sample being closer the results of the research group. Thus, the control group obtained better results by $0.62^{\circ}$ on average.

Following the application of the method researched in the paper, namely the viewing of recordings from the first evaluation with biomechanically analyzed frames, the relationship between the two groups changes. At the final evaluation, the research group obtained results closer to the execution model in all 6 samples, on average by $-4.61^{\circ}$.

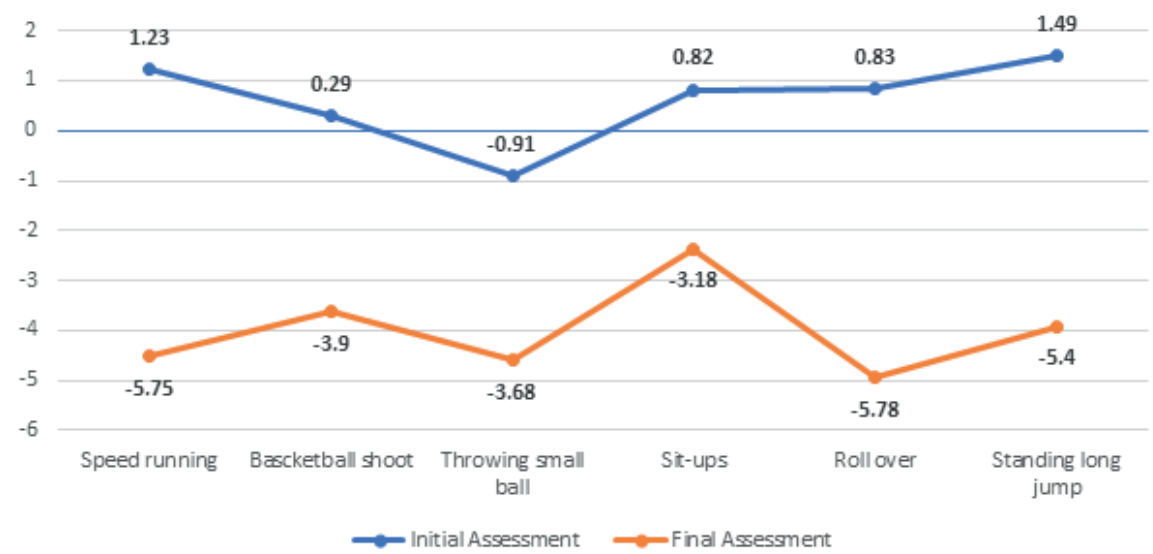

Fig. 7. The results obtained by both groups compared to the execution model and the difference between the two groups

Positive values show better results in the control group, while negative values show superior results in the research group. Thus, we can observe an obvious progress of the research group at the final evaluation, compared to the execution model, reaching much closer values than the control group.

\section{DISCUSSION}

Students' performance during physical education and sports classes can be observed through the possibilities offered by multimedia techniques, their efficiency in the field of physical education, forcing teachers to introduce these new elements in the classes. 
Recording the students' execution and viewing these videos leads to modeling the correct execution and forming the image of one's own movement, by detecting mistakes, in a much more efficient way than the "old" methods, based on explanations and instructions [17-20].

The method of biomechanical analysis of executions with the help of multimedia techniques leads to an efficient and objective evaluation through a possibility of interpreting and revising the execution itself at different times with the use of slowing down the image and enlarging it.

Analysis of the results of biomechanical assessment and motor performance shows that correcting the execution technique ensures progress in the results obtained in technical procedures, where the measurement does not require repeating the same exercise several times over a period of time. Thus in evaluation tests where only one execution is measured: speed running, throwing a small ball and long jump the correction of the execution technique leads to an increase in motor performance, while in evaluation tests where the execution is repeated in a time interval measuring the number of repetitions, such as sit-ups, the correction of execution mistakes by increasing the amplitude of the movement leads to a decrease in the number of repetitions [21].

\section{CONCLUSIONS}

The results obtained after applying the means of video recording and analysis, coming as a support for the teacher, and their use in the educational instructional process, ensure a progress in students' technical preparation, with mistakes being detected more easily and more concretely and students forming a clear image of their own execution and mistakes.

The method used in the research has shown that providing minimum equipment - a recording camera and specialized software, introduction of multimedia methods in the instructionaleducational process in physical education and sports is as simple and viable as possible in each pre-university education institution.

Following the application of the method investigated in the paper, namely the viewing of biomechanically analyzed recordings from the first evaluation, we observe a progress of the research group compared to the control group, with subjects obtaining results closer to the execution model in all 6 samples, on average by $4.61^{\circ}$.

\section{REFERENCES}

[1] Maroti, Ş., Metodologia cercetării ştiinţifice în educaţie fizică şi sport, [Methodology of scientific research in physical education and sport]. Oradea: Editura Universităţii din Oradea; 2008. Romanian.

[2] Marcu V, Buhaş SD. Sports organizations-management and science. Procedia-Social and Behavioral Sciences. 2014; 117:678-682. https://doi.org/10.1016/j.sbspro.2014.02.281

[3] Dragoș P, Lucaciu G, Dinis I, Ștef Gavriș M, Szabo-Alexi P, Buhaș S. Concepts Concerning the Content of Children's Training in Some Sport Games. Proceedings of the 4th International Conference of the Universitaria Consortium (ICU 2018): The Impact of Sport and Physical Education Science on Today's Society. Bologna; 2018, 67-72.

[4] Buhaș SD, Stance L. The Relationship between Personality and Physical Activity. GeoSport Soc. 2017;7(2):72-77.

[5] Cristea DI, Motoc I, Pop AC. Aspects regarding the integration of children with special educational needs through participation in physical education. BaltJ Health Phys Act. 2020;SpecIssue1:79-86. https://doi.org/10.29359/BJHPA.12. Spec.Iss1.09

[6] Herman GV, Banto N, Caciora T, et al. Tourism in Bihor County, Romania. Trends and Prospects. Folia Geogr. 2020;62:87-105.

[7] Olszewski-Strzyżowski DJ. European societies' access to sport-the European Union actions. GeoSport Soc. 2018;9(2):71-81.

[8] Nor A, Patar A, Mohd Nor Azmi Hokyoo L, Shin-ichiroh Y, Jamaluddin M. Biomechanical analysis using Kinovea for sports application. IOP Conference Series: Materials Science and Engineering. 2018;342. https://doi.org/10.1088/1757899X/342/1/012097 
[9] Puig-Diví A, Escalona-Marfil C, Padullés-Riu JM, Busquets A, Padullés-Chando X, Marcos-Ruiz D. Validity and reliability of the Kinovea program in obtaining angles and distances using coordinates in 4 perspectives PLoS ONE. 2019; 14(6):e0216448. https://doi.org/10.1371/journal.pone.0216448

[10] Pocsai I. Studiu privind utilizarea înregistrării video în analiza execuţiei tehnicilor de karate, [Study regarding the use of video images in analisys of tehnical aspects in karate] Oradea: Universitatea din Oradea; 2011. Romanian.

[11] Galer M, Horvat L. Imaginea digitală, aplicații, [Digital image, applications]. București: Editura Ad Libri; 2004. Romanian.

[12] Ilieș DC, Buhaș R, Ilieș A, et al. Indoor Air Quality Issues. Case Study: The Multipurpose Sport Hall of the University of Oradea. Environ Eng Manag J (EEMJ). 2018;17(12):2999-3005.

[13] Cristea D, Cristea A, Dragos P. Considerations regarding pedagogical practice of physical education students at gymnasium. GeoSport Soc. 2017;6:47.

[14] Cristea D, Hosu A, Ille M, (2019) Studiu privind ameliorarea ambidextriei la copiii de 11-12 ani [Study regarding improving of ambidexterity for children of 11-12 years]. Revista Română de Kinetoterapie. 2019;25(42):19-27. Romanian.

[15] Maştei D, Szabo P. Operare pe calculator - îndrumar lucrări practice [Operating the PC - practical guide, Oradea: Editura Universităţii din Oradea; 2001. Romanian.

[16] Szabo-Alexi P, Hanţiu I, Szabo-Alexi M. Evaluarea acţiunilor de joc - prezentarea programului de analiză video "Dartfish" - exemplificări din volei, [Evaluation of game actions - presentation of the video analysis program "Dartfish" - examples from volleyball. Analele Universităţii din Oradea, Fascicula Educaţie Fizică şi Sport. 2008;2:146-153. Romanian.

[17] Thomas JR, Nelson JK, Silverman SJ. Research methods in physical activity. Champaign, Ill: Human Kinetics; 2010.

[18] Holzinger A. A multimédia alapjai. [The basics of multimedia]. Budapesta: Editura Kiskapu; 2004. Hungarian.

[19] Livari D. Idee e modelli di progettazione nei processi formativi, Ideas and design models in training processes, Roma: Editura Lavoro; 1987.

[20] Szabo-Alexi P, Ilieș A, Szabo-Alexi M. The Romanian cultural-sports scenery defined by volleyball competitions through structure, dynamics and systemic functionality during 2009-2016. GeoSport Soc. 2016;4(1):51-68.

[21] Stubbs R. Sportok konyve: Sportagak, Versenyek, Taktikak, Tehnikak [Sports Book: Sports, Competitions, Tactics, Techniques]. Budapesta: Editura Mérték; 2009. Hungarian. 